\title{
Penerapan Metode Topsis Pada Peningkatan Kinerja Karyawan
}

\author{
Nicodias Palasara ${ }^{1}$, Taufik Baidawi ${ }^{2}$ \\ ${ }^{1}$ STMIK Nusa Mandiri Jakarta \\ e-mail: nico.ncp@nusamandiri.ac.id \\ ${ }^{2}$ AMIK BSI Sukabumi \\ e-mail: taufiq.tfb@bsi.ac.id
}

\begin{abstract}
Abstrak
Hasil dari kinerja karyawan dapat dijadikan sebuah peluang untuk para pegawai dan perusahaan dalam melihat kemampuan serta potensi dari sisi internal. Dari hasil tersebut perusahaan dapat mengetahui dan melihat tingkat kinerja dari seluruh karyawan yang ada. Dengan standar penilaian tingkat kinerja karyawan yang sudah dibuat oleh perusahan sebanyak 14 kriteria. Namun, keputusan akhir biasanya melibatkan penilaian manusia yang besar. Kekurangan penilaian tanpa adanya metode pendukung keputusan maka seperti penilian tradisional, metodenya adalah manusia yang dikenal rentan terhadap bias, meskipun pimpinan yang lebih berpengalaman namun ada penilaian yang subjektif. Maka dari itu penulis memasukkan metode sistem pendukung keputusan agar penilaian yang dihasilkan dapat memberikan nilai objektif. Maka penulis mencoba mengambil sebuah metode TOPSIS yang diharapkan dapat menyelesaikan dan memberikan sebuah solusi dari permasalahan yang ada. Topsis menggunakan indikator kriteria dan variable alternatif sehinga dapat membantu untuk menentukan keputusan, komputasinya efisien, perhitungan komputasinya lebih efisien dan dan cepat, mampu dijadikan sebagai pengukur kinerja alternatif dan juga alternatif keputusan dalams sebuah bentuk output komputasi yang sederhana, dan dapat digunakan sebagai metode pengambilan keputusan yang lebih cepat.
\end{abstract}

Keywords: TOPSIS, Kinerja Karyawan, Pendukung Keputusan

\begin{abstract}
The results of employee performance can be used as an opportunity for employees and companies to see their internal capabilities and potential. From these results the company can find out and see the level of performance of all existing employees. With a standard assessment of the level of employee performance that has been made by the company as many as 14 criteria. However, the final decision usually involves a large human assessment. Lack of assessment without decision support methods, such as traditional assessment, the method is that people are known to be vulnerable to bias, even though the leaders are more experienced but there are subjective judgments. Therefore the author includes a decision support system method so that the resulting assessment can provide objective value. So the author tries to take a TOPSIS method which is expected to solve and provide a solution to the existing problems. Topsis uses alternative criteria and variable indicators so that it can help to determine decisions, efficient computation, computation calculations are more efficient and fast, able to be used as an alternative performance gauge and also an alternative decision in a simple form of computational output, and can be used as a decision making method faster.
\end{abstract}

Keywords: TOPSIS, Employee Performance, Decision Support

\section{Pendahuluan \\ Kinerja kayawan merupakan hal \\ yang bersifat individual karena tiap karyawan memiliki tingkat kemampuan yang berbeda-beda, maka tingkat kinerja karyawan menjadi salah satu faktor}

terpenting dalam setiap perusahaan. Sehingga memiliki karyawan yang berkualitas tinggi dapat menentukan keberhasilan suatu perusahaan. Hasil dari kinerja karyawan dapat dijadikan sebuah peluang untuk para pegawai dan 
perusahaan dalam melihat kemampuan serta potensi dari sisi internal. Dari hasil tersebut perusahaan dapat mengetahui dan melihat tingkat kinerja dari seluruh karyawan yang ada. Dan dari pihak karyawan, melihat adanya potensi untuk mendapatkan penghargaan dari prestasi yang mereka perbuat, sehingga penilaian kinerja karyawan menjadi bahan evaluasi dan semangat bagi karyawan untuk meningkatkan kualitas kerjanya. Penelitian ini adalah pengembangan dari penelitian sebelumnya pada jurnal penelitian Sistem Pengambilan Keputusan Pemilihan Karyawan Terbaik Menggunakan Metode Analytic Hierarchy Process (Palasara, 2017) .

Dengan standar penilaian tingkat kinerja karyawan yang sudah dibuat oleh perusahan sebanyak 14 kriteria antara lain:

1. Kuantitas Kerja

Banyaknya hasil pekerjaan yang telah dihasilkan oleh karyawan dengan waktu yang sudah ditentukan oleh perusahaan.

2. Kualitas Kerja

Menunjukkan sejauh mana mutu seorang karyawan dalam melaksanakan tugas-tugasnya meliputi ketepatan, kelengkapan, dan kerapian.

3. Kejujuran

Sifat yang melekat dalam diri karyawan dan merupakan hal penting untuk dilakukan khususnya pada saat karyawan tersebut menemui masalah pekerjaan yang berhubungan dengan kepercayaan.

4. Tanggung Jawab

Kesadaran karyawan akan tingkah laku atau perbuatannya yang di sengaja maupun yang tidak di sengaja dalam melaksanakan pekerjaannya.

5. Motivasi Diri

Kemampuan untuk mendapatkan alasan atau dorongan untuk bertindak dalam situasi dimanapun.

6. Dedikasi

Sebuah pengorbanan tenaga, pikiran, dan waktu karyawan dalam melakasakan pekerjaan yang diberikan, demi keberhasilan suatu usaha yang mempunyai tujuan yang mulia.

7. Ketrampilan Kerja

Kemampuan atau kecakapan untuk melakukan sesuatu sesuai dengan tugasnya.
8. Penampilan

Bentuk peryataan diri atas penampilan yang menarik dan menimbulkan rasa percaya diri.

9. Inisiatif

Kemampuan karyawan untuk bertindak melebihi yang dibutuhkan atau yang dituntut dari suatu pekerjaan.

10. Pemanfaatan Waktu Ketepatan waktu dalam kehadiran dan penyelesaian tugas yang diberikan oleh perusahaan.

11. Kerjasama

Pekerjaan yang biasanya dikerjakan oleh individu tapi dikerjakan secara bersamaan oleh dua orang atau lebih dengan tujuan agar pekerjaan tersebut menjadi lebih ringan.

12. Komunikasi

Suatu proses penyampaian informasi seperti pesan, ide, gagasan karyawan dari satu pihak kepada pihak lain

13. Disiplin

Sikap karyawan yang selalu tepat janji, sehingga pimpinan atau orang lain mempercayai dirinya.

14. Kehadiran

Ketepatan waktu seseorang untuk datang dan melaksanakan tugasnya, sesuai dengan waktu yang ditentuka perusahaan.

Sistem dikatakan baik dan akan berhasil digunakan atau diterapkan jika didukung beberapa unsur atau aspek (Anggraini et al., 2018).

Penilaian tanpa adanya metode pendukung keputusan maka keputusan akhir akan melibatkan pendapat manusia yang besar, dengan kata lain penilaian tersebut menjadi subjectif. Penilaian dengan menggunakan metode Multi Attribute Decision Making sangat cocok untuk pengambilan keputusan yang berisikan data kualitatif. Banyak metode yang bisa dipergunakan untuk membantu mendukung sebuah keputusan. Multi Attribute Decision Making merupakan salah satu metode pendukung pengambilan keputusan yang cukup baik dan dapat menjadi salah satu alternatif untuk mengambil keputusan jika alternative atau attribute yang digunakan cukup banyak dan bernilai data kuantitatif.

Beberapa metode yang dapat membantu memberikan alternatif terbaik diantaranya: Analytic Hierarchy Prosess (AHP), Simple Additive Weighting (SAW), Technique for Order Preference by 
Similarity to Ideal Solution (TOPSIS). Pada penelitian yang berjudul TOPSIS Method Application for Decision Support System in Internal Control for Selecting Best Employees (Rahim et al., 2018), peneiltian ini menggunakan metode topsis dalam perhitungannya dengan 4 kriteria yaitu tanggung jawab, disiplin kerja, kualitas kerja, prilaku, dengan kesimpulan bahwa penggunaan metode topsis tepat dipergunakan dalam penelitian tersebut. Lalu penelitian dengan judul Comparison Analysis of TOPSIS and Fuzzy Logic Methods On Fertilizer Selection (Indahingwati et al., 2018), penelitian tersbut membandingkan metode topsis dengan metode fuzzy logic, dimana topsis menggunakan prinsip alternatif yang dipilih jarak terpendek sedangkan fuzzy logic metode pemecahan sistem kontrol dengan penilaian biner yaitu true or false, kesimpulannya bahwa metode TOPSIS mendapatkan nilai relatif NPK dengan persentase $33,6 \%$ sedangkan dengan Metode Fuzzy Logic mendapatkan hasil Fuzzy Logic yaitu pupuk NPK dengan persentase $38,6 \%$.

Melihat dari penelitian diatas, maka penulis mencoba mengambil sebuah metode TOPSIS dengan 14 kriteria yang diharapkan dapat menyelesaikan dan memberikan sebuah solusi dari permasalahan yang ada. Keuntungan utama dari TOPSIS dibanding dengan Metode MADM lainnya dalam pengambilan keputusan masalah yang kompleks adalah mudah digunakan, dapat memperhitungkan semua jenis kriteria (subyektif dan obyektif), logika rasional dan mudah dipahami bagi para praktisi, perhitungan proses sangat mudah, konsep memungkinkan mengejar kriteria alternatif terbaik digambarkan dalam matematika secara sederhana, dan bobot penting dapat dimasukkan dengan mudah (Nasab et al., 2012).

TOPSIS adalah metode beberapa kriteria untuk mengidentifikasi solusi dari satu set alternatif terbatas (Ashtiani et al., 2009). Prinsip dasarnya adalah bahwa alternative yang dipilih harus memiliki jarak terpendek dari solusi ideal positif dan jarak terjauh dari solusi ideal negatif. Dalam TOPSIS, rating kinerja dan bobot kriteria tersebut diberikan sebagai niai crips. (Rouhani, S., Mehdi, G., Mostafa, 2012). TOPSIS banyak digunakan untuk memecahkan masalah MCDM.

\section{Metode Penelitian}

Untuk menganalisa data dengan menggunakan metode TOPSIS diperlukan data dari populasi yang disebut data sampel atau responden. Oleh karena itu, teknik responden ini tidak dilakukan secara acak, namun sudah ditentukan berdasarkan pertimbangan atau sampling purposive. Untuk mengelolah data menggunakan perhitungan manual dari metode TOPSIS dalam menentukan karyawan terbaik dan kebijakan perusahaan sebagai tolak ukur tercapainya penelitian ini.Adapun langkahlangkah penelitian sebagai berikut:

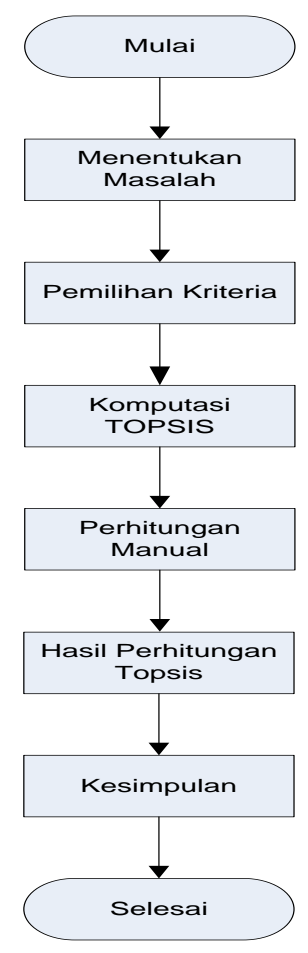

Gambar 1. Langka-langkah Penelitian Sumber: Penelitian 2018

\section{Metode Pengumpulan data}

Dalam penelitian ini menggunakan teknik purposive sampling karena menganalisa data dari responden dalam satu populasi. Dimana, responden yang dipilih tidak dilakukan secara acak tetapi berdasarkan kebijakan perusahaan. Responden yang digunakan dalam penelitian ini sebanyak 3 responden yaitu

\begin{tabular}{|l|l|}
\hline \multicolumn{1}{|c|}{ Tabel 1. Data Responden } \\
\hline 1 orang & Kepala Divisi \\
\hline 1 orang & Kepala Departement \\
\hline 1 orang & Kepala Unit \\
\hline \multicolumn{2}{|c|}{ Sumber: Penelitian 2018}
\end{tabular}


Tabel 2. Data Karyawan

\begin{tabular}{|l|c|}
\hline \multicolumn{1}{|c|}{ Nama Karyawan } & Inisial \\
\hline Adi Prasetyo & P1 \\
\hline Bobi Bramantyo & P2 \\
\hline Rina Dwiana & P3 \\
\hline Erika & P4 \\
\hline Arie Martanto & P5 \\
\hline Rizki Agus Wibowo & P6 \\
\hline Wartono Akhpino & P7 \\
\hline I Kadek Ruwa & P8 \\
\hline Fadilah Noor & P9 \\
\hline Randie Aulia & P10 \\
\hline
\end{tabular}

Sumber: Penelitian 2018

Tabel 3. Ratting Kepentingan

\begin{tabular}{|l|c|}
\hline $\begin{array}{c}\text { Nama } \\
\text { Kepentingan }\end{array}$ & Score \\
\hline Penting & 3 \\
\hline Cukup Penting & 2 \\
\hline Kurang Penting & 1 \\
\hline
\end{tabular}

Sumber: Penelitian 2018

Tabel 4 Nilai Parameter Nilai Parameter

\begin{tabular}{|c|c|}
\hline \multicolumn{2}{|c|}{ Nilai Parameter } \\
\hline Penting & 1,000000 \\
\hline Cukup Penting & 0,666667 \\
\hline Kurang Penting & 0,333333 \\
\hline
\end{tabular}

Sumber: Penelitian 2018

Tabel 5 Tabel Variabel

\begin{tabular}{|c|l|l|}
\hline Fungsi & \multicolumn{1}{|c|}{ Nama Variabel } & Inisial \\
\hline \multirow{4}{*}{ Input } & Kuantitas Kerja & K1 \\
\cline { 2 - 3 } & Kualitas Kerja & K2 \\
\cline { 2 - 3 } & Kejujuran & K3 \\
\cline { 2 - 3 } & Tanggung Jawab & K4 \\
\cline { 2 - 3 } & Motivas Diri & K5 \\
\cline { 2 - 3 } & Dedikasi & K6 \\
\cline { 2 - 3 } & Penampilan & K7 \\
\cline { 2 - 3 } & Ketrampilan Kerja & K8 \\
\cline { 2 - 3 } & Inisiatif & K9 \\
\cline { 2 - 3 } & Pemanfaatan Waktu & K10 \\
\cline { 2 - 3 } & Kerjasama & K11 \\
\cline { 2 - 3 } & Komunikasi & K12 \\
\cline { 2 - 3 } & Disiplin & K14 \\
\cline { 2 - 3 } & Kehadiran & \\
\hline Output & Metode yang Lebih Cocok \\
\cline { 2 - 3 } & Seleksi Karyawan yang Terbaik \\
\hline
\end{tabular}

Sumber: Penelitian 2018

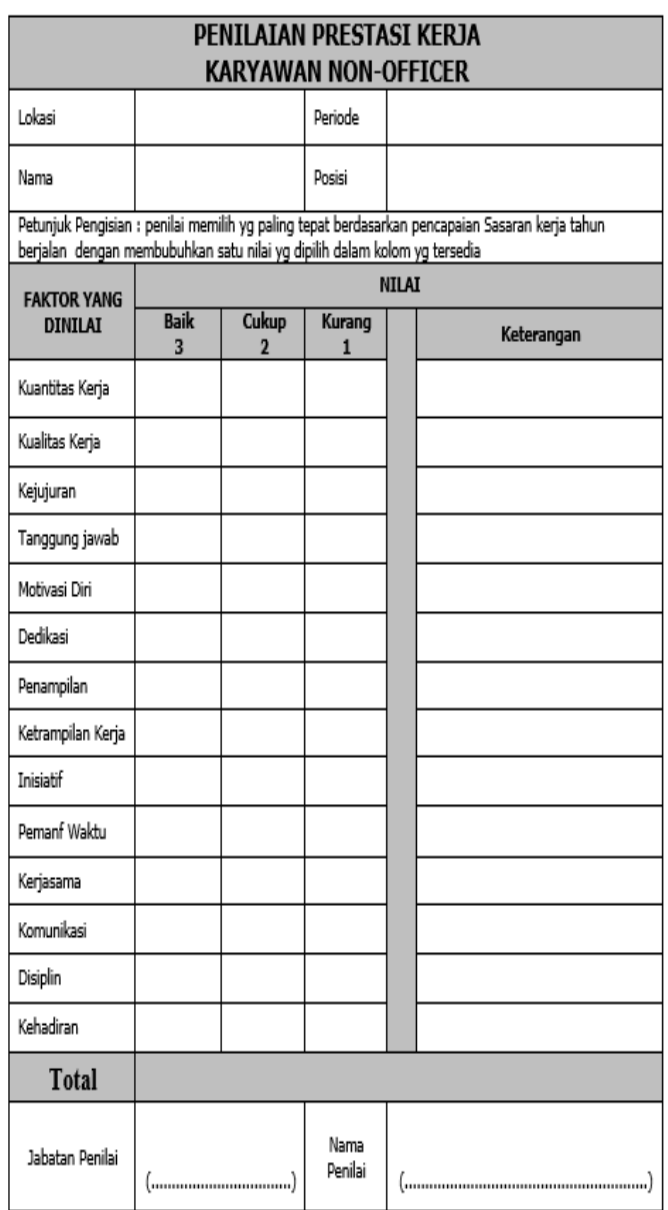

Gambar 2. Form Penilaian Karyawan Sumber: Penelitian 2018

Tabel 6. Bobot Kepetingan Variable

\begin{tabular}{|l|c|c|}
\hline \multicolumn{1}{|c|}{ Nama Variable } & $\begin{array}{c}\text { Nama } \\
\text { Kepentingan }\end{array}$ & Score \\
\hline Kuantitas Kerja & Penting & 3 \\
\hline Kualitas Kerja & Penting & 3 \\
\hline Kejujuran & Penting & 3 \\
\hline Tanggung Jawab & Cukup Penting & 2 \\
\hline Motivas Diri & Kurang Penting & 1 \\
\hline Dedikasi & Cukup Penting & 2 \\
\hline Penampilan & Cukup Penting & 2 \\
\hline Ketrampilan Kerja & Cukup Penting & 2 \\
\hline Inisiatif & Cukup Penting & 2 \\
\hline Pemanfaatan Waktu & Cukup Penting & 2 \\
\hline Kerjasama & Kurang Penting & 1 \\
\hline Komunikasi & Cukup Penting & 2 \\
\hline Disiplin & Penting & 3 \\
\hline Kehadiran & Penting & 3 \\
\hline
\end{tabular}

Sumber: Penelitian 2018 


\section{Hasil dan Pembahasan}

Pengolahan data Technique for Order Preference by Similarity to Ideal Solution (TOPSIS):

1.Membuat sebuah nominasi matriks berdasarkan rekap data kuesioner

Tabel 7. Nominasi Matriks

\begin{tabular}{|c|c|c|c|c|c|c|c|c|c|c|c|c|c|c|c|}
\hline No & Karyawan & K1 & K2 & K3 & K4 & K5 & K6 & K7 & K8 & K9 & K10 & K11 & K12 & K13 & K14 \\
\hline 1 & P1 & 3 & 3 & 3 & 3 & 2 & 3 & 3 & 2 & 3 & 3 & 3 & 3 & 2 & 3 \\
\hline 2 & P2 & 3 & 3 & 3 & 3 & 3 & 3 & 3 & 3 & 3 & 3 & 1 & 2 & 2 & 3 \\
\hline 3 & P3 & 2 & 2 & 3 & 3 & 3 & 3 & 3 & 3 & 3 & 3 & 3 & 2 & 3 & 3 \\
\hline 4 & P4 & 3 & 3 & 3 & 3 & 3 & 3 & 3 & 3 & 3 & 3 & 3 & 3 & 3 & 3 \\
\hline 5 & P5 & 2 & 1 & 2 & 3 & 2 & 3 & 2 & 2 & 3 & 2 & 2 & 1 & 1 & 2 \\
\hline 6 & P6 & 1 & 1 & 2 & 2 & 3 & 2 & 3 & 2 & 2 & 2 & 1 & 1 & 1 & 2 \\
\hline 7 & P7 & 2 & 2 & 2 & 2 & 3 & 3 & 3 & 3 & 2 & 2 & 3 & 1 & 2 & 2 \\
\hline 8 & P8 & 3 & 3 & 3 & 1 & 3 & 3 & 2 & 3 & 3 & 3 & 2 & 1 & 3 & 3 \\
\hline 9 & P9 & 3 & 3 & 3 & 3 & 3 & 3 & 3 & 3 & 3 & 3 & 2 & 3 & 2 & 3 \\
\hline 10 & P10 & 1 & 2 & 2 & 3 & 3 & 2 & 3 & 3 & 3 & 2 & 2 & 1 & 1 & 3 \\
\hline
\end{tabular}

2. Merubah nominasi kedalam fuzzy yang telah ditetapkan yang disebut dengan defuzzyfikasi.

Tabel 8. Defuzzyfikasi

\begin{tabular}{|c|c|c|c|c|c|c|c|c|c|c|c|c|c|c|c|}
\hline No & KR & K1 & K2 & K3 & K4 & K5 & K6 & K7 & K8 & K9 & K10 & K11 & K12 & K13 & K14 \\
\hline \multirow{2}{*}{1} & P1 & 1,0 & 0,6 & 1,0 & 1,0 & 0,6 & 1,0 & 1,0 & 0,6 & 1,0 & 1,0 & 1,0 & 1,0 & 0,6 & 1,0 \\
& 00 & 67 & 00 & 00 & 67 & 00 & 00 & 67 & 00 & 00 & 00 & 00 & 67 & 00 \\
\hline \multirow{2}{*}{2} & P2 & 1,0 & 1,0 & 1,0 & 1,0 & 1,0 & 1,0 & 1,0 & 1,0 & 1,0 & 1,0 & 0,3 & 0,6 & 0,6 & 1,0 \\
& & 00 & 00 & 00 & 00 & 00 & 00 & 00 & 00 & 00 & 00 & 33 & 67 & 67 & 00 \\
\hline \multirow{2}{*}{3} & P3 & 1,0 & 1,0 & 1,0 & 1,0 & 1,0 & 1,0 & 1,0 & 1,0 & 1,0 & 1,0 & 1,0 & 0,6 & 1,0 & 1,0 \\
& & 00 & 00 & 00 & 00 & 00 & 00 & 00 & 00 & 00 & 00 & 00 & 67 & 00 & 00 \\
\hline \multirow{2}{*}{4} & P4 & 1,0 & 1,0 & 1,0 & 1,0 & 0,6 & 1,0 & 1,0 & 1,0 & 1,0 & 1,0 & 0,6 & 1,0 & 1,0 & 1,0 \\
& & 00 & 00 & 00 & 00 & 67 & 00 & 00 & 00 & 00 & 00 & 67 & 00 & 00 & 00 \\
\hline \multirow{2}{*}{5} & \multirow{2}{*}{ P5 } & 0,6 & 0,3 & 0,6 & 1,0 & 0,6 & 1,0 & 0,6 & 0,6 & 1,0 & 0,6 & 0,6 & 0,3 & 0,3 & 0,6 \\
& 67 & 33 & 67 & 00 & 67 & 00 & 67 & 67 & 00 & 67 & 67 & 33 & 33 & 00 \\
\hline \multirow{2}{*}{6} & $\mathrm{P} 6$ & 0,3 & 0,3 & 0,6 & 0,6 & 1,0 & 0,6 & 1,0 & 0,6 & 0,6 & 0,6 & 0,3 & 0,3 & 0,3 & 0,6 \\
& 33 & 33 & 67 & 67 & 00 & 67 & 00 & 67 & 67 & 67 & 33 & 33 & 33 & 00 \\
\hline \multirow{2}{*}{7} & $\mathrm{P} 7$ & 0,6 & 0,6 & 0,6 & 0,6 & 1,0 & 1,0 & 1,0 & 1,0 & 0,6 & 0,6 & 1,0 & 0,3 & 0,6 & 0,6 \\
& 67 & 67 & 67 & 67 & 00 & 00 & 00 & 00 & 67 & 67 & 00 & 33 & 67 & 00 \\
\hline \multirow{2}{*}{8} & $\mathrm{P} 8$ & 1,0 & 1,0 & 1,0 & 0,3 & 1,0 & 1,0 & 0,6 & 1,0 & 1,0 & 1,0 & 0,6 & 0,3 & 1,0 & 1,0 \\
& 00 & 00 & 00 & 33 & 00 & 00 & 67 & 00 & 00 & 00 & 67 & 33 & 00 & 00 \\
\hline \multirow{2}{*}{9} & $\mathrm{P} 9$ & 1,0 & 1,0 & 1,0 & 1,0 & 1,0 & 1,0 & 1,0 & 1,0 & 1,0 & 1,0 & 0,6 & 1,0 & 0,6 & 1,0 \\
& 00 & 00 & 00 & 00 & 00 & 00 & 00 & 00 & 00 & 00 & 67 & 00 & 67 & 00 \\
\hline \multirow{2}{*}{10} & $\mathrm{P} 1$ & 0,3 & 0,6 & 0,6 & 1,0 & 1,0 & 0,6 & 1,0 & 1,0 & 1,0 & 0,6 & 0,6 & 0,3 & 0,3 & 1,0 \\
& 0 & 33 & 67 & 67 & 00 & 00 & 67 & 00 & 00 & 00 & 67 & 67 & 33 & 33 & 00 \\
\hline
\end{tabular}

3.Melakukan normalisasi matriks

$$
\text { Sumber: Penelitian } 2018
$$

Tabel 9. Hasil Normalisasi Matriks

\begin{tabular}{|c|c|c|c|c|c|c|c|c|c|c|c|c|c|c|c|}
\hline No & KR & K1 & K2 & K3 & K4 & K5 & K6 & K7 & K8 & K9 & K10 & K11 & K12 & K13 & K14 \\
\hline \multirow{2}{*}{1} & P1 & 0,3 & 0,2 & 0,3 & 0,3 & 0,2 & 0,3 & 0,3 & 0,2 & 0,3 & 0,3 & 0,4 & 0,4 & 0,2 & 0,3 \\
& & 75 & 60 & 59 & 54 & 31 & 35 & 35 & 31 & 35 & 59 & 29 & 74 & 95 & 52 \\
\hline \multirow{2}{*}{2} & P2 & 0,3 & 0,3 & 0,3 & 0,3 & 0,3 & 0,3 & 0,3 & 0,3 & 0,3 & 0,3 & 0,1 & 0,3 & 0,2 & 0,3 \\
& & 75 & 91 & 59 & 54 & 46 & 35 & 35 & 46 & 35 & 59 & 43 & 16 & 95 & 52 \\
\hline \multirow{2}{*}{3} & P3 & 0,3 & 0,3 & 0,3 & 0,3 & 0,3 & 0,3 & 0,3 & 0,3 & 0,3 & 0,3 & 0,4 & 0,3 & 0,4 & 0,3 \\
& & 75 & 91 & 59 & 54 & 46 & 35 & 35 & 46 & 35 & 59 & 29 & 16 & 42 & 52 \\
\hline \multirow{2}{*}{4} & P4 & 0,3 & 0,3 & 0,3 & 0,3 & 0,2 & 0,3 & 0,3 & 0,3 & 0,3 & 0,3 & 0,2 & 0,4 & 0,4 & 0,3 \\
& & 75 & 91 & 59 & 54 & 31 & 35 & 35 & 46 & 35 & 59 & 86 & 74 & 42 & 52 \\
\hline
\end{tabular}




\begin{tabular}{|c|c|c|c|c|c|c|c|c|c|c|c|c|c|c|c|}
\hline 5 & P5 & $\begin{array}{l}0,2 \\
50\end{array}$ & $\begin{array}{l}0,1 \\
30\end{array}$ & $\begin{array}{l}0,2 \\
39\end{array}$ & $\begin{array}{l}0,3 \\
54\end{array}$ & $\begin{array}{l}0,2 \\
31\end{array}$ & $\begin{array}{l}0,3 \\
35\end{array}$ & $\begin{array}{l}0,2 \\
24 \\
\end{array}$ & $\begin{array}{l}0,2 \\
31\end{array}$ & $\begin{array}{l}0,3 \\
35\end{array}$ & $\begin{array}{l}0,2 \\
39\end{array}$ & $\begin{array}{l}0,2 \\
86\end{array}$ & $\begin{array}{l}0,1 \\
58\end{array}$ & $\begin{array}{l}0,1 \\
47 \\
\end{array}$ & $\begin{array}{l}0,2 \\
11\end{array}$ \\
\hline 6 & P6 & 0,1 & 0,1 & 0,2 & 0,2 & 0,3 & 0,2 & 0,3 & 0,2 & 0,2 & 0,2 & 0,1 & 0,1 & 0,1 & 0,2 \\
\hline & & 25 & 30 & 39 & 36 & 46 & 24 & 35 & 31 & 24 & 39 & 43 & 58 & 47 & 11 \\
\hline 7 & P7 & $\begin{array}{l}0,2 \\
50\end{array}$ & $\begin{array}{l}0,2 \\
60\end{array}$ & $\begin{array}{l}0,2 \\
39\end{array}$ & $\begin{array}{l}0,2 \\
36\end{array}$ & $\begin{array}{l}0,3 \\
46\end{array}$ & $\begin{array}{l}0,3 \\
35\end{array}$ & $\begin{array}{l}0,3 \\
35\end{array}$ & $\begin{array}{l}0,3 \\
46\end{array}$ & $\begin{array}{l}0,2 \\
24\end{array}$ & $\begin{array}{l}0,2 \\
39\end{array}$ & $\begin{array}{l}0,4 \\
29\end{array}$ & $\begin{array}{l}0,1 \\
58\end{array}$ & $\begin{array}{l}0,2 \\
95\end{array}$ & $\begin{array}{l}0,2 \\
11\end{array}$ \\
\hline 8 & P8 & $\begin{array}{l}0,3 \\
75\end{array}$ & $\begin{array}{l}0,3 \\
91\end{array}$ & $\begin{array}{l}0,3 \\
59\end{array}$ & $\begin{array}{l}0,1 \\
18\end{array}$ & $\begin{array}{l}0,3 \\
46\end{array}$ & $\begin{array}{l}0,3 \\
35\end{array}$ & $\begin{array}{l}0,2 \\
24\end{array}$ & $\begin{array}{l}0,3 \\
46\end{array}$ & $\begin{array}{l}0,3 \\
35\end{array}$ & $\begin{array}{l}0,3 \\
59\end{array}$ & $\begin{array}{l}0,2 \\
86\end{array}$ & $\begin{array}{l}0,1 \\
58\end{array}$ & $\begin{array}{l}0,4 \\
42\end{array}$ & $\begin{array}{l}0,3 \\
52\end{array}$ \\
\hline 9 & P9 & $\begin{array}{l}0,3 \\
75\end{array}$ & $\begin{array}{l}0,3 \\
91\end{array}$ & $\begin{array}{l}0,3 \\
59\end{array}$ & $\begin{array}{l}0,3 \\
54\end{array}$ & $\begin{array}{l}0,3 \\
46\end{array}$ & $\begin{array}{l}0,3 \\
35\end{array}$ & $\begin{array}{l}0,3 \\
35\end{array}$ & $\begin{array}{l}0,3 \\
46\end{array}$ & $\begin{array}{l}0,3 \\
35\end{array}$ & $\begin{array}{l}0,3 \\
59\end{array}$ & $\begin{array}{l}0,2 \\
86\end{array}$ & $\begin{array}{l}0,4 \\
74\end{array}$ & $\begin{array}{l}0,2 \\
95\end{array}$ & $\begin{array}{l}0,3 \\
52\end{array}$ \\
\hline 10 & $\begin{array}{c}\mathrm{P} 1 \\
0\end{array}$ & $\begin{array}{l}0,1 \\
25\end{array}$ & $\begin{array}{l}0,2 \\
60\end{array}$ & $\begin{array}{l}0,2 \\
39\end{array}$ & $\begin{array}{l}0,3 \\
54\end{array}$ & $\begin{array}{l}0,3 \\
46\end{array}$ & $\begin{array}{l}0,2 \\
24\end{array}$ & $\begin{array}{l}0,3 \\
35\end{array}$ & $\begin{array}{l}0,3 \\
46\end{array}$ & $\begin{array}{l}0,3 \\
35\end{array}$ & $\begin{array}{l}0,2 \\
39\end{array}$ & $\begin{array}{l}0,2 \\
86\end{array}$ & $\begin{array}{l}0,1 \\
58\end{array}$ & $\begin{array}{l}0,1 \\
47\end{array}$ & $\begin{array}{l}0,3 \\
52\end{array}$ \\
\hline
\end{tabular}

Sumber: Penelitian 2018

4.Setelah matriks dibuatkan normalisasinya, selanjutnya dilakukan pembobotan, maka akan didapatkan hasil matriks terbobot seperti dibawah ini :

Tabel 10. Hasil pembobotan Topsis

\begin{tabular}{|c|c|c|c|c|c|c|c|c|c|c|c|c|c|c|c|}
\hline No & KRY & K1 & K2 & K3 & K4 & K5 & K6 & K7 & K8 & K9 & K10 & K11 & K12 & $\mathrm{K} 13$ & K14 \\
\hline 1 & P1 & 0,38 & 0,26 & 0,36 & 0,24 & 0,08 & 0,22 & 0,22 & 0,15 & 0,22 & 0,24 & 0,14 & 0,32 & 0,29 & 0,35 \\
\hline 2 & P2 & 0,38 & 0,39 & 0,36 & 0,24 & 0,12 & 0,22 & 0,22 & 0,23 & 0,22 & 0,24 & 0,05 & 0,21 & 0,29 & 0,35 \\
\hline 3 & P3 & 0,38 & 0,39 & 0,36 & 0,24 & 0,12 & 0,22 & 0,22 & 0,23 & 0,22 & 0,24 & 0,14 & 0,21 & 0,44 & 0,35 \\
\hline 4 & $\mathrm{P} 4$ & 0,38 & 0,39 & 0,36 & 0,24 & 0,08 & 0,22 & 0,22 & 0,23 & 0,22 & 0,24 & 0,10 & 0,32 & 0,44 & 0,35 \\
\hline 5 & P5 & 0,25 & 0,13 & 0,24 & 0,24 & 0,08 & 0,22 & 0,15 & 0,15 & 0,22 & 0,16 & 0,10 & 0,11 & 0,15 & 0,21 \\
\hline 6 & P6 & 0,13 & 0,13 & 0,24 & 0,16 & 0,12 & 0,15 & 0,22 & 0,15 & 0,15 & 0,16 & 0,05 & 0,11 & 0,15 & 0,21 \\
\hline 7 & P7 & 0,25 & 0,26 & 0,24 & 0,16 & 0,12 & 0,22 & 0,22 & 0,23 & 0,15 & 0,16 & 0,14 & 0,11 & 0,29 & 0,21 \\
\hline 8 & P8 & 0,38 & 0,39 & 0,36 & 0,08 & 0,12 & 0,22 & 0,15 & 0,23 & 0,22 & 0,24 & 0,10 & 0,11 & 0,44 & 0,35 \\
\hline 9 & P9 & 0,38 & 0,39 & 0,36 & 0,24 & 0,12 & 0,22 & 0,22 & 0,23 & 0,22 & 0,24 & 0,10 & 0,32 & 0,29 & 0,35 \\
\hline 10 & P10 & 0,13 & 0,26 & 0,24 & 0,24 & 0,12 & 0,15 & 0,22 & 0,23 & 0,22 & 0,16 & 0,10 & 0,11 & 0,15 & 0,35 \\
\hline
\end{tabular}

Sumber: Penelitian 2018

5.Setelah melakukan pembobotan matriks, selanjutnya dicari solusi positif dan negatif dari setiap kriteria seperti tabel dibawah ini :

Tabel 10. Solusi Positif dan Negatif

\begin{tabular}{|l|l|l|l|l|l|l|l|l|l|l|l|l|l|l|}
\hline & $\mathrm{K} 1$ & $\mathrm{~K} 2$ & $\mathrm{~K} 3$ & $\mathrm{~K} 4$ & $\mathrm{~K} 5$ & $\mathrm{~K} 6$ & $\mathrm{~K} 7$ & $\mathrm{~K} 8$ & $\mathrm{~K} 9$ & $\mathrm{~K} 10$ & $\mathrm{~K} 11$ & $\mathrm{~K} 12$ & $\mathrm{~K} 13$ & $\mathrm{~K} 14$ \\
\hline Positif(+) & 0,375 & 0,39 & 0,359 & 0,24 & 0,12 & 0,22 & 0,22 & 0,23 & 0,22 & 0,24 & 0,14 & 0,32 & 0,44 & 0,35 \\
\hline Negatif(-) & 0,125 & 0,13 & 0,239 & 0,08 & 0,08 & 0,15 & 0,15 & 0,15 & 0,15 & 0,16 & 0,05 & 0,11 & 0,15 & 0,21 \\
\hline
\end{tabular}

\section{Sumber: Penelitian 2018}

6.Setelah didapat nilai dari solusi positif dan negatif maka selanjutnya dicari nilai dari alternative masing-masing solusi. Maka hasil dari pencarian alternatif positif akan menghasilkan nilai tabel dibawah ini :

Tabel 11. Hasil Alternatif Positif

\begin{tabular}{|c|c|c|c|c|c|c|c|c|c|c|c|c|c|c|c|c|}
\hline $\begin{array}{l}N \\
0\end{array}$ & $\begin{array}{l}\mathrm{K} \\
\mathrm{R} \\
\mathrm{Y}\end{array}$ & K1 & K2 & K3 & K4 & K5 & K6 & K7 & K8 & K9 & $\begin{array}{c}\text { K1 } \\
0\end{array}$ & $\begin{array}{c}\mathrm{K} 1 \\
1\end{array}$ & $\begin{array}{c}\text { K1 } \\
2\end{array}$ & $\begin{array}{c}\text { K1 } \\
3\end{array}$ & $\begin{array}{c}\text { K1 } \\
4\end{array}$ & $\begin{array}{l}\text { TOTA } \\
\text { L }\end{array}$ \\
\hline 1 & P1 & $\begin{array}{r}0,0 \\
00 \\
\end{array}$ & $\begin{array}{r}0,1 \\
30 \\
\end{array}$ & $\begin{array}{r}0,0 \\
00 \\
\end{array}$ & $\begin{array}{r}0,0 \\
00 \\
\end{array}$ & $\begin{array}{r}0,0 \\
38 \\
\end{array}$ & $\begin{array}{r}0,0 \\
00 \\
\end{array}$ & $\begin{array}{r}0,0 \\
00 \\
\end{array}$ & $\begin{array}{r}0,0 \\
77 \\
\end{array}$ & $\begin{array}{r}0,0 \\
00 \\
\end{array}$ & $\begin{array}{r}0,0 \\
00 \\
\end{array}$ & $\begin{array}{r}0,0 \\
00 \\
\end{array}$ & $\begin{array}{r}0,0 \\
00 \\
\end{array}$ & $\begin{array}{r}0,1 \\
47 \\
\end{array}$ & $\begin{array}{r}0,0 \\
00 \\
\end{array}$ & $\begin{array}{r}0,393 \\
101 \\
\end{array}$ \\
\hline 2 & P2 & $\begin{array}{r}0,0 \\
00\end{array}$ & $\begin{array}{r}0,0 \\
00\end{array}$ & $\begin{array}{r}0,0 \\
00\end{array}$ & $\begin{array}{r}0,0 \\
00\end{array}$ & $\begin{array}{r}0,0 \\
00\end{array}$ & $\begin{array}{r}0,0 \\
00\end{array}$ & $\begin{array}{r}0,0 \\
00\end{array}$ & $\begin{array}{r}0,0 \\
00\end{array}$ & $\begin{array}{r}0,0 \\
00\end{array}$ & $\begin{array}{r}0,0 \\
00\end{array}$ & $\begin{array}{r}0,0 \\
95\end{array}$ & $\begin{array}{r}0,1 \\
05\end{array}$ & $\begin{array}{l}0,1 \\
47\end{array}$ & $\begin{array}{r}0,0 \\
00\end{array}$ & $\begin{array}{r}0,348 \\
089\end{array}$ \\
\hline 3 & P3 & $\begin{array}{r}0,0 \\
00 \\
\end{array}$ & $\begin{array}{r}0,0 \\
00 \\
\end{array}$ & $\begin{array}{r}0,0 \\
00 \\
\end{array}$ & $\begin{array}{r}0,0 \\
00 \\
\end{array}$ & $\begin{array}{r}0,0 \\
00 \\
\end{array}$ & $\begin{array}{r}0,0 \\
00 \\
\end{array}$ & $\begin{array}{r}0,0 \\
00 \\
\end{array}$ & $\begin{array}{r}0,0 \\
00 \\
\end{array}$ & $\begin{array}{r}0,0 \\
00 \\
\end{array}$ & $\begin{array}{r}0,0 \\
00 \\
\end{array}$ & $\begin{array}{r}0,0 \\
00 \\
\end{array}$ & $\begin{array}{r}0,1 \\
05 \\
\end{array}$ & $\begin{array}{r}0,0 \\
00 \\
\end{array}$ & $\begin{array}{r}0,0 \\
00 \\
\end{array}$ & $\begin{array}{r}0,105 \\
409 \\
\end{array}$ \\
\hline 4 & P4 & $\begin{array}{r}0,0 \\
00 \\
\end{array}$ & $\begin{array}{r}0,0 \\
00 \\
\end{array}$ & $\begin{array}{r}0,0 \\
00 \\
\end{array}$ & $\begin{array}{r}0,0 \\
00 \\
\end{array}$ & $\begin{array}{r}0,0 \\
38 \\
\end{array}$ & $\begin{array}{r}0,0 \\
00 \\
\end{array}$ & $\begin{array}{r}0,0 \\
00 \\
\end{array}$ & $\begin{array}{r}0,0 \\
00 \\
\end{array}$ & $\begin{array}{r}0,0 \\
00 \\
\end{array}$ & $\begin{array}{r}0,0 \\
00 \\
\end{array}$ & $\begin{array}{r}0,0 \\
48 \\
\end{array}$ & $\begin{array}{r}0,0 \\
00\end{array}$ & $\begin{array}{r}0,0 \\
00\end{array}$ & $\begin{array}{r}0,0 \\
00\end{array}$ & $\begin{array}{r}0,086 \\
109 \\
\end{array}$ \\
\hline 5 & P5 & 0,1 & 0,2 & 0,1 & 0,0 & 0,0 & 0,0 & 0,0 & 0,0 & 0,0 & 0,0 & 0,0 & 0,2 & 0,2 & 0,1 & 1,468 \\
\hline
\end{tabular}




\begin{tabular}{|c|c|c|c|c|c|c|c|c|c|c|c|c|c|c|c|c|}
\hline & & 25 & 60 & 20 & 00 & 38 & 00 & 75 & 77 & 00 & 80 & 48 & 11 & 95 & 41 & 629 \\
\hline & & 0,2 & 0,2 & 0,1 & 0,0 & 0,0 & 0,0 & 0,0 & 0,0 & 0,0 & 0,0 & 0,0 & 0,2 & 0,2 & 0,1 & 1,755 \\
\hline 6 & P6 & 50 & 60 & 20 & 79 & 00 & 75 & 00 & 77 & 75 & 80 & 95 & 11 & 95 & 41 & 861 \\
\hline & & 0,1 & 0,1 & 0,1 & 0,0 & 0,0 & 0,0 & 0,0 & 0,0 & 0,0 & 0,0 & 0,0 & 0,2 & 0,1 & 0,1 & 1,106 \\
\hline 7 & P7 & 25 & 30 & 20 & 79 & 00 & 00 & 00 & 00 & 75 & 80 & 00 & 11 & 47 & 41 & 477 \\
\hline & & 0,0 & 0,0 & 0,0 & 0,1 & 0,0 & 0,0 & 0,0 & 0,0 & 0,0 & 0,0 & 0,0 & 0,2 & 0,0 & 0,0 & 0,490 \\
\hline 8 & P8 & 00 & 00 & 00 & 57 & 00 & 00 & 75 & 00 & 00 & 00 & 48 & 11 & 00 & 00 & 108 \\
\hline 9 & $P Q$ & 0,0 & 0,0 & 0,0 & 0,0 & 0,0 & 0,0 & 0,0 & 0,0 & 0,0 & 0,0 & 0,0 & 0,0 & 0,1 & 0,0 & 0,195 \\
\hline$y$ & Py & 00 & 00 & 00 & 00 & 00 & 00 & 00 & 00 & 00 & 00 & 48 & 00 & 47 & 00 & 061 \\
\hline 1 & P1 & 0,2 & 0,1 & 0,1 & 0,0 & 0,0 & 0,0 & 0,0 & 0,0 & 0,0 & 0,0 & 0,0 & 0,2 & 0,2 & 0,0 & 1,207 \\
\hline 0 & 0 & 50 & 30 & 20 & 00 & 00 & 75 & 00 & 00 & 00 & 80 & 48 & 11 & 95 & 00 & 251 \\
\hline
\end{tabular}

Sumber: Penelitian 2018

Dan hasil dari alternatif positif pada Adi Prasetyo adalah 0.393, Budi Bramantyo adalah 0,348, Rina Dwiana adalah 0,105, Erika adalah 0,086, Arie Martanto adalah 1,443, Rizki Agus Wibowo adalah 1,730, Wartono Akhpino adalah 1,081, Kadek Ruwa adalah 0,490, Fadilah Noor adalah 0,195 , Randie Aulia adalah 1,20. Sedangkan untuk pencarian alternatif negatif adalah:

Tabel 12. Hasil Alternatif Negatif

\begin{tabular}{|c|c|c|c|c|c|c|c|c|c|c|c|c|c|c|c|c|}
\hline $\mathrm{N}$ & $\mathrm{K}$ & & & & & & & & & & & \\
$\mathrm{R}$ & $\mathrm{K} 1$ & $\mathrm{~K} 2$ & $\mathrm{~K} 3$ & $\mathrm{~K} 4$ & $\mathrm{~K} 5$ & $\mathrm{~K} 6$ & $\mathrm{~K} 7$ & $\mathrm{~K} 8$ & $\mathrm{~K} 9$ & $\begin{array}{c}\mathrm{K} 1 \\
0\end{array}$ & $\begin{array}{c}\mathrm{K} 1 \\
1\end{array}$ & $\begin{array}{c}\mathrm{K} 1 \\
2\end{array}$ & $\begin{array}{c}\mathrm{K} 1 \\
3\end{array}$ & $\begin{array}{c}\mathrm{K} 1 \\
4\end{array}$ & $\begin{array}{c}\mathrm{TOT} \\
\mathrm{AL}\end{array}$ \\
\hline \multirow{2}{*}{1} & $\mathrm{P}$ & 0,2 & 0,1 & 0,1 & 0,1 & 0,0 & 0,0 & 0,0 & 0,0 & 0,0 & 0,0 & 0,0 & 0,2 & 0,1 & 0,1 & 1,55 \\
& 1 & 50 & 30 & 20 & 57 & 00 & 75 & 75 & 00 & 75 & 80 & 95 & 11 & 47 & 41 & 4353 \\
\hline \multirow{2}{*}{2} & $\mathrm{P}$ & 0,2 & 0,2 & 0,1 & 0,1 & 0,0 & 0,0 & 0,0 & 0,0 & 0,0 & 0,0 & 0,0 & 0,1 & 0,1 & 0,1 & 1,59 \\
& 2 & 50 & 60 & 20 & 57 & 38 & 75 & 75 & 77 & 75 & 80 & 00 & 05 & 47 & 41 & 9365 \\
\hline \multirow{2}{*}{3} & $\mathrm{P}$ & 0,2 & 0,2 & 0,1 & 0,1 & 0,0 & 0,0 & 0,0 & 0,0 & 0,0 & 0,0 & 0,0 & 0,1 & 0,2 & 0,1 & 1,84 \\
& 3 & 50 & 60 & 20 & 57 & 38 & 75 & 75 & 77 & 75 & 80 & 95 & 05 & 95 & 41 & 2045 \\
\hline \multirow{2}{*}{4} & $\mathrm{P}$ & 0,2 & 0,2 & 0,1 & 0,1 & 0,0 & 0,0 & 0,0 & 0,0 & 0,0 & 0,0 & 0,0 & 0,2 & 0,2 & 0,1 & 1,86 \\
& 4 & 50 & 60 & 20 & 57 & 00 & 75 & 75 & 77 & 75 & 80 & 48 & 11 & 95 & 41 & 1345 \\
\hline \multirow{2}{*}{5} & $\mathrm{P}$ & 0,1 & 0,0 & 0,0 & 0,1 & 0,0 & 0,0 & 0,0 & 0,0 & 0,0 & 0,0 & 0,0 & 0,0 & 0,0 & 0,0 & 0,47 \\
& 5 & 25 & 00 & 00 & 57 & 00 & 75 & 00 & 00 & 75 & 00 & 48 & 00 & 00 & 00 & 8825 \\
\hline \multirow{2}{*}{6} & $\mathrm{P}$ & 0,0 & 0,0 & 0,0 & 0,0 & 0,0 & 0,0 & 0,0 & 0,0 & 0,0 & 0,0 & 0,0 & 0,0 & 0,0 & 0,0 & 0,19 \\
& 6 & 0 & 00 & 00 & 79 & 38 & 00 & 75 & 00 & 00 & 00 & 00 & 00 & 00 & 00 & 1593 \\
\hline \multirow{2}{*}{7} & $\mathrm{P}$ & 0,1 & 0,1 & 0,0 & 0,0 & 0,0 & 0,0 & 0,0 & 0,0 & 0,0 & 0,0 & 0,0 & 0,0 & 0,1 & 0,0 & 0,84 \\
& 7 & 25 & 30 & 00 & 79 & 38 & 75 & 75 & 77 & 00 & 00 & 95 & 00 & 47 & 00 & 0978 \\
\hline \multirow{2}{*}{8} & $\mathrm{P}$ & 0,2 & 0,2 & 0,1 & 0,0 & 0,0 & 0,0 & 0,0 & 0,0 & 0,0 & 0,0 & 0,0 & 0,0 & 0,2 & 0,1 & 1,45 \\
& 8 & 50 & 60 & 20 & 00 & 38 & 75 & 00 & 77 & 75 & 80 & 48 & 00 & 95 & 41 & 7346 \\
\hline \multirow{2}{*}{9} & $\mathrm{P}$ & 0,2 & 0,2 & 0,1 & 0,1 & 0,0 & 0,0 & 0,0 & 0,0 & 0,0 & 0,0 & 0,0 & 0,2 & 0,1 & 0,1 & 1,75 \\
& 9 & 50 & 60 & 20 & 57 & 38 & 75 & 75 & 77 & 75 & 80 & 48 & 11 & 47 & 41 & 2393 \\
\hline 1 & $\mathrm{P}$ & 0,0 & 0,1 & 0,0 & 0,1 & 0,0 & 0,0 & 0,0 & 0,0 & 0,0 & 0,0 & 0,0 & 0,0 & 0,0 & 0,1 & 0,74 \\
0 & 10 & 00 & 30 & 00 & 57 & 38 & 00 & 75 & 77 & 75 & 00 & 48 & 00 & 00 & 41 & 0204 \\
\hline
\end{tabular}

\section{Sumber: Penelitian 2018}

Dan hasil dari alternatif negatif pada Adi Prasetyo adalah 1,529, Budi Bramantyo adalah 1,574, Rina Dwiana adalah 1,816, Erika adalah 1,836, Arie Martanto adalah 0,478, Rizki Agus Wibowo adalah 0,191, Wartono Akhpino adalah 0,840 , Kadek Ruwa adalah 1,432, Fadilah Noor adalah 1,727, Randie Aulia adalah 0,714.

7.Jika semua alternatif sudah mendapatkan nilai alternatif positif dan negatifnya maka selanjutnya dilakukan pencarian nilai preferensi untuk masing-masing alternatif.
Dan nilai untuk preferensi Adi Prasetyo adalah 0,79549, Budi Bramantyo adalah 0,81891, Rina Dwiana adalah 0,94516, Erika adalah 0,95520, Arie Martanto adalah 0,24910, Rizki Agus Wibowo adalah 0,09967, Wartono Akhpino adalah 0,43750, Kadek Ruwa adalah 0,74502, Fadilah Noor adalah 0,89852, Randie Aulia adalah 0,37194 .

8. Hasil akhir untuk penilaian kayawan dengan menggunakan metode TOPSIS adalah: 
Tabel 13. Hasil Perankingan Metode TOPSIS

\begin{tabular}{|c|c|c|}
\hline Nama Kry & Nilai & Rangking \\
\hline Erika & 0,955203 & 1 \\
\hline Rina Dwiana & 0,9451623 & 2 \\
\hline Fadilah Noor & 0,8985223 & 3 \\
\hline Bobi Bramantyo & 0,8189114 & 4 \\
\hline Adi Prasetyo & 0,7954948 & 5 \\
\hline I Kadek Ruwa & 0,7450282 & 6 \\
\hline Wartono Akhpino & 0,4375068 & 7 \\
\hline Randie Aulia & 0,3719448 & 8 \\
\hline Arie Martanto & 0,249102 & 9 \\
\hline Rizki Agus Wibowo & 0,0996736 & 10 \\
\hline
\end{tabular}

Sumber: Penelitian 2018

\section{Kesimpulan}

Berdasarkan hasil analisa diatas dapat dikatakan bahwa Topsis memiliki konsep sederhana dan mudah dipahami, kesedarhanaan ini dilihat dari alur proses metode TOPSIS yang tidak begitu rumit. Karena menggunakan indikator kriteria dan variable alternatif sebagai pembantu untuk menentukan keputusan, komputasinya efisien, perhitungan komputasinya lebih efisien dan dan cepat, mampu dijadikan sebagai pengukur kinerja alternatif dan juga alternatif keputusan dalams sebuah bentuk output komputasi yang sederhana, dan dapat digunakan sebagai metode pengambilan keputusan yang lebih cepat. Untuk penelitian kedepan, bisa dibuat perhitungan dengan metode penggabungan TOPSIS dan AHP.

\section{Referensi}

Anggraini, F. S., \& Palasara, N. (2018).

Perancangan Program Inventory Sparepart Alat Berat Pada PT. Conbloc Infratecno Jakarta. Jurnal Inovasi Informatika, 3(1), 35-45.

Ashtiani, B., Haghighirad, F.,Makui, A., Montazer, G.A.(2008). Extension of Fuzzy TOPSIS Method Based on Interval-valued Fuzzy Sets. Applied Soft Computing. Vol. 9, No.2, 457461.

Indahingwati, A., Wajdi, M. B. N., Susilo,D. E., Kurniasih, N., \& Rahim, R. (2018). Comparison Analysis of TOPSIS and Fuzzy Logic Methods On Fertilizer Selection.
International Journal of Engineering \& Technology, 7(2.3), 109-114.

Nasab, H.H., Milani, A.S.(2012). An improvement of Quantitative Strategic Planning Matrix Using Multiple Criteria Decision Making and Fuzzy Numbers. Applied Soft Computing 12, 2246- 2253.

Palasara, N. (2017). Sistem Pengambilan Keputusan Pemilihan Karyawan Terbaik Menggunakan Metode Analytic Hierarchy Process. Bina Insani ICT Journal, 4(1), 31-46.

Rahim, R., Supiyandi, S., Siahaan, A. P. U., Listyorini, T., Utomo, A. P., Triyanto, W. A., \& Khairunnisa, K. (2018, June). TOPSIS Method Application for Decision Support System in Internal Control for Selecting Best Employees. In Journal of Physics: Conference Series (Vol. 1028, No. 1, p. 012052). IOP Publishing.

Rouhani, S., Mehdi, G., Mostafa, J.

(2012). Evaluation model of business intelligence for enterprise system using fuzzy TOPSIS. Expert Systems with Applications, (39). 